\title{
Sphingosylphosphorylcholine and lysosulfatide have inverse regulatory functions in monocytic cell differentiation into macrophages.
}

\section{$\operatorname{AUTHOR}(\mathrm{S}):$}

Yamamoto, Hiroshi; Naito, Yuko; Okano, Maho; Kanazawa, Takayuki; Takematsu, Hiromu; Kozutsumi, Yasunori

\section{CITATION:}

Yamamoto, Hiroshi ...[et al]. Sphingosylphosphorylcholine and lysosulfatide have inverse regulatory functions in monocytic cell differentiation into macrophages.. Archives of biochemistry and biophysics 2011, 506(1): 83-91

\section{ISSUE DATE:}

2011-02-01

URL:

http://hdl.handle.net/2433/134801

\section{RIGHT:}

(c) 2010 Elsevier Inc.; この論文は出版社版でありません。引用の際には 出版社版をご確認ご利用ください。; This is not the published version. Please cite only the published version. 
Sphingosylphosphorylcholine and lysosulfatide have inverse regulatory functions in monocytic cell differentiation into macrophages

Hiroshi Yamamoto $^{\text {a, b }}$, Yuko Naito ${ }^{\mathrm{a}, \mathrm{b}}$, Maho Okano ${ }^{\mathrm{a}, \mathrm{b}}$, Takayuki Kanazawa ${ }^{\mathrm{a}}$, Hiromu Takematsu $^{\text {a, b }}$, and Yasunori Kozutsumi ${ }^{\text {a, b, * }}$

From ${ }^{\mathrm{a}}$ Laboratory of Membrane Biochemistry and Biophysics, Graduate School of Biostudies, Kyoto University, Sakyo, Kyoto 606-8501, Japan, ${ }^{\mathrm{b}}$ CREST, JST, Kawaguchi, Saitama, Japan

"Correspondence author. Address: Laboratory of Membrane Biochemistry and Biophysics, Graduate School of Biostudies, Kyoto University, Yoshida-shimoadachi, Sakyo, Kyoto 606-8501, Japan Tel: +81-75-753-7684; Fax: +81-75-753-7686; E-mail: yasu@pharm.kyoto-u.ac.jp 


\begin{abstract}
Sphingolipids act as signaling mediators that regulate a diverse range of cellular events. Although numerous sphingolipid functions have been studied, little is known about the effect of sphingolipids on monocyte differentiation into macrophages. Here, we report that two lysosphingolipids, sphingosylphosphorylcholine (SPC) and lysosulfatide (LSF), inversely affect macrophagic differentiation of monocytic cell lines, U937 and THP-1. Molecular analyses revealed that SPC enhances, whereas LSF suppresses, phorbol ester-induced classical (M1-polarized) differentiation to macrophages. The expression of CD11b, a macrophage marker, was induced in accordance with the activation status of the Raf/MEK/ERK signaling pathway in which SPC and LSF had opposite effects. Pharmacological inhibition of this pathway aborted the differentiation, indicating that this signaling pathway is required. Consistently, SPC promoted, while LSF inhibited, monocyte adhesion to fibronectin, through the phosphatidylinositol-3-kinase (PI3K)/Akt signaling pathway. The effects of SPC on Raf/MEK/ERK and PI3K/Akt signaling were dependent on $\mathrm{G}_{\mathrm{i} / \mathrm{o}}$, whereas the SPC-induced calcium influx was dependent on $\mathrm{G}_{\mathrm{q}}$. Thus SPC utilizes G-protein coupled receptor. In contrast, the effects of LSF were independent of $G_{i / o}$ and $G_{q}$. These results suggest that SPC enhances, whereas LSF suppresses, monocyte differentiation into macrophages through regulating the Raf/MEK/ERK and PI3K/Akt signaling pathways via distinct mechanisms.
\end{abstract}

\title{
1.1 Keywords
}

lysosphingolipid, intracellular signaling, sphingolipids, macrophage, differentiation 


\subsection{INTRODUCTION}

Sphingolipids, which consist of a long-chain hydrophobic tail and a polar head group, are essential components of cellular membranes or membrane microdomain [1]. In addition to their function as components, recent studies have revealed that sphingolipids could be employed as signaling mediators, regulating diverse cellular events that include proliferation, migration, adhesion, and differentiation. Therefore, sphingolipids, such as ceramide, sphingosine, sphingosine-1-phosphate (S1P), ceramide-1-phosphate, and sphingosylphosphorylcholine (SPC), are regarded as "bioactive lipids" [2]. However, activities of sphingolipids are not uniform; some sphingolipids actually mediate opposite consequences in the cells. For example, sphingosine and ceramide induce apoptosis $[3,4]$ whereas S1P promotes cell survival [5]. These cellular effects may be transmitted by receptor molecules. S1P is a ligand for the G-protein-coupled receptors (GPCR) $\mathrm{S}_{1} \mathrm{P}_{1-5}$ and S1P promotes cell adhesion and cell migration via S1P receptors [6,7]. However, not all bioactive sphingolipids have authentic receptors.

In addition to studies on the cellular level, the function of sphingolipid(s) in animal model has been examined using ISP-1/myriocin, an inhibitor for biosynthesis of sphingolipids [8]. ISP-1/myriocin administered to apolipoprotein E-deficient mice, a widely used animal model for atherosclerosis, caused a decrease in plasma sphingolipid levels and a reduction in atherosclerosis area [9]. Therefore, expression of sphingolipid(s) could be required for the progression of atherosclerosis, although the molecular species involved in this model is currently not identified. Monocyte-derived and classically activated (M1 polarized) macrophages have essential roles in the progression of atherosclerosis [10]. Circulating blood monocytes differentiate into macrophages in various tissues in the course of reaching the cell periphery, and thus correct monocytic differentiation to macrophages is an important step for appropriate immune function [11]. Recent studies have shown that S1P regulates lymphocyte trafficking [12,13]. Furthermore, studies have suggested that lipid species such as lysophosphatidic acid (LPA) or S1P enhance integrin-mediated B lymphocyte adhesion through G-proteins, analogous to the activities of chemokines [14,15]. Therefore, we postulated that sphingolipids may regulate monocyte differentiation into macrophages.

Several studies have reported that the phorbol ester, 12-O-tetradecanoylphorbol 13-acetate (TPA), could trigger monocyte differentiation into M1 macrophages through activating protein kinase $\mathrm{C}$ in monocytic cell lines [16,17]. In the present study, we found that two lyosphingolipid species, SPC and lysosulfatide (LSF), have inverse regulatory effects on 
TPA-triggered cellular adhesion and macrophagic differentiation of monocytic cell lines, U937 and THP-1 cells. Molecular targets for the regulatory effect of these sphingolipids (SPC to promote and LSF to inhibit) involve the regulation of the Raf/MEK/ERK and phosphatidylinositol-3-kinase (PI3K)/Akt signaling pathways. 


\section{Materials and Methods}

\subsection{Chemicals}

SPC, fibronectin, and fatty acid-free BSA were purchased from Sigma (St. Louis, MO). 1-Oleoyl-sn-glycero-3-phosphate (LPA) and S1P were obtained from Cayman Chemical Co. (Ann Arbor, MI). All other lipids were from Matreya (Pleasant Gap, PA). 12-O-Tetradecanoylphorbol 13-acetate (TPA), PD98509, and LY294002 were obtained from Calbiochem (San Diego, CA) and pertussis toxin (PTX) was purchased from Seikagaku Kogyo (Tokyo, Japan). Blasticidin was obtained from Nacalai Tesque (Kyoto, Japan).

\subsection{Antibodies}

We used the following antibodies: a rabbit monoclonal antibody against phospho-Raf-1 (Ser338) and rabbit polyclonal antibodies against phospho-ERK1/2 (Thr202/Tyr204), ERK1/2, phospho-MEK1/2 (Ser217/221), MEK1/2, phospho-Akt (Ser473), and Akt (Cell Signaling Technology, Beverly, MA); rabbit polyclonal antibodies against Raf-1 (Santa Cruz Biotechnology, Santa Cruz, CA); a mouse monoclonal antibody against CD11b/Mac1 (ICRF44) and a fluorescein isothiocyanate (FITC)-conjugated rat anti-mouse $\operatorname{IgG}_{1}$ (BD Pharmingen, San Diego, CA); a mouse monoclonal antibody against CD206/ macrophage mannose receptor (15-2) (AbD Serotec, Kindlington); and a horseradish peroxidase (HRP)-conjugated goat anti-rabbit IgG (Zymed Laboratories, South San Francisco, CA).

\subsection{Cell culture}

U937 human monocytic cells and THP-1 human monocytic cells were obtained from the American Type Culture Collection (Manassas, VA) and the European Collection of Cell Cultures (Salisbury, Wiltshire, UK), respectively. U937 cells and THP-1 cells were cultured in RPMI1640-HEPES medium (Nacalai Tesque, Kyoto, Japan) supplemented with 10\% fetal bovine serum (FBS) (JRH, Lenexa, KS), sodium pyruvate (Invitrogen, Carlsbad, CA), nonessential amino acids (Invitrogen), and 2-mercaptoethanol (Nacalai Tesque). Serum starvation was carried out in the RPMI1640 containing $0.25 \%$ fatty acid-free BSA overnight. The Plat-A cells and Plat-E cells were kindly provided by Dr. Toshio Kitamura (University of 
Tokyo, Tokyo, Japan). Plat-A cells and Plat-E cells were cultured in Dulbecco's modified Eagle's medium (DMEM) (Nacalai Tesque) supplemented with 10\% FBS [18]. RH7777 cells stably expressing $\mathrm{LPA}_{2}\left(\mathrm{LPA}_{2}\right.$ cells) were a generous gift from Dr. Fumikazu Okajima (Gunma University, Gunma, Japan) and were characterized previously [19]. LPA 2 cells were maintained in $\alpha$-MEM (Nacalai Tesque) supplemented with $10 \%$ FBS and $250 \mu \mathrm{g} / \mathrm{ml} \mathrm{G418.}$

\subsection{Cell adhesion assay}

To assess the effect of LSF and SPC on cellular adhesion to fibronectin, 96-well flat-bottomed plates were coated with $50 \mu$ fibronectin $(10 \mu \mathrm{g} / \mathrm{ml})$ overnight at $4^{\circ} \mathrm{C}$ and blocked with $100 \mu 10.5 \%$ BSA in phosphate-buffered saline (PBS) for at least $1 \mathrm{~h}$ at $37^{\circ} \mathrm{C}$. U937 cells $\left(1 \times 10^{6}\right.$ cells $\left./ \mathrm{ml}\right)$ in RPMI1640 containing $0.25 \%$ BSA were stimulated with LSF or SPC for $1 \mathrm{~h}$ at $37^{\circ} \mathrm{C}$ in the fibronectin-coated 96-wells plates. XTT assay was carried out to monitor adherent cells.

\subsection{Flow cytometry}

U937 cells $\left(1 \times 10^{5}\right.$ cells $\left./ \mathrm{ml}\right)$ and THP-1 cells $\left(2 \times 10^{5}\right.$ cells $\left./ \mathrm{ml}\right)$ were incubated in the presence or absence of S1P $(1 \mu \mathrm{M})$, LSF $(5 \mu \mathrm{M})$, or SPC $(10 \mu \mathrm{M})$ for $16 \mathrm{~h}$, followed by treatment with or without TPA $(1 \mathrm{ng} / \mathrm{ml})$ for $72 \mathrm{~h}$. Unless stated, medium contained FBS to support cell growth. In some experiments, medium was supplied with FBS that was pretreated with charcoal so that some of the content such as lipids was depleted. To determine whether SPC enhances TPA-induced differentiation through the Raf/MEK/ERK or PI3K signaling pathway, cells were pretreated with or without PD98059 (50 $\mu \mathrm{M})$, LY294002 (2 $\mu \mathrm{M})$ for $15 \mathrm{~min}$ prior to the SPC stimulation. The cells were washed with PBS once and resuspended in fluorescence-activated cell sorter buffer (1\% FBS and $0.1 \% \mathrm{NaN}_{3}$ in PBS). Cells were incubated with anti-CD11b/Mac-1 antibody or CD206 antibody for 45 min at room temperature. Cells were then labeled with FITC-conjugated rat anti-mouse $\operatorname{IgG}_{1}$ for 30 min at room temperature. Data were acquired using a FACScan (BD Biosciences, Franklin Lakes, NJ) instrument and analyzed using FlowJo software (Tree Star, San Carlos, CA).

\subsection{RT-PCR}

Total RNAs were prepared (RNeasy Mini; Qiagen, Valencia, CA) and reverse transcribed. 
First strand cDNA was subjected to PCR in which various buffer, annealing temperatures and cycles were optimized to ensure template dose-dependent amplification. The primer pairs used were as follows: IL12B (212 bp), 5'-TGTCTGCCAGGATGTATGGA-3', 5'-TATCTCTTGCGTTCCCATCC-3'; $\quad$ IL10 (293 bp), 5'-TTACCTGGAGGAGGTGATGC-3'， 5'-ATAGAGTCGCCACCCTGATG-3'; IL6 (208 bp), 5'-AGTTCCTGCAGAAAAAGGCA-3', 5'-AACAACAATCTGAGGTGCCC-3'; TGFB1 (361 bp), 5'-GCCACAGATCCCCTATTCAA-3', 5'-TCTTGCAGGTGGATAGTCCC-3'; FCER2 (272 bp), 5'-TCAGGACTTGGAGCTGTCCT-3'， 5'-CCATGTCGTCACAGGCATAC-3'; G3PDH $(983$ $\mathrm{bp})$, 5'-TGAAGGTCGGAGTCAACGGATTTGGT-3', 5'-CATGTGGGCCATGAGGTCCACCAC-3'; Ga $\alpha_{\mathrm{q}}$-I (214bp), 5'-ATGGCTTACCCATACGACGT-3', 5'-CCAGATTGTACTCCTTCAGG-3'.

\subsection{Western blotting}

To test the inhibitory effect of LSF on the Raf/MEK/ERK and PI3K/Akt signaling pathways, U937 cells and THP-1 cells $\left(5 \times 10^{5}\right.$ cells $\left./ \mathrm{ml}\right)$ were incubated with LSF for $16 \mathrm{~h}$, and then stimulated with TPA $(1 \mathrm{ng} / \mathrm{ml})$ for $5 \mathrm{~min}$. To test the stimulatory effect of SPC or S1P on the Raf/MEK/ERK and PI3K/Akt signaling pathways, serum-starved cells $\left(1 \times 10^{6}\right.$ cells $\left./ \mathrm{ml}\right)$ were stimulated with SPC $(10 \mu \mathrm{M})$ or S1P $(1 \mu \mathrm{M})$ for the indicated time. Cells were washed once with ice-cold PBS and lysed with ice-cold cell lysis buffer [10 mM Tris-HCl (pH 7.4), $150 \mathrm{mM} \mathrm{NaCl}, 1 \mathrm{mM}$ EDTA, 1\% Triton-X100, protease inhibitor cocktail (Nacalai Tesque)]. The chemiluminescence signal was detected using a HRP substrate (Chemi-Lumi One; Nacalai Tesque) and a Luminoimage Analyzer LAS-3000 (Fujifilm, Tokyo, Japan).

\subsection{Retrovirus infection}

The receptor-G $\alpha_{\mathrm{q}}$ interaction-blocking "mini gene" $\left(G \alpha_{q}-I\right)$, which corresponds to the C-terminal peptide sequence of $\mathrm{G} \alpha_{\mathrm{q}}$ residues 305-359, subcloned into pcDNA3, was a kind gift from Dr. Jun Takasaki (Astellas Pharma Inc., Tokyo, Japan) [20]. $G \alpha_{q^{-}} I$ was subcloned into the modified mouse stem cell viral vector pMSCV (Clontech, Mountain View, CA) carrying an internal ribosomal entry site (Clontech) and resistance gene for blasticidin (Invitrogen). Virus was prepared by transient transfection to Plat-A or Plat-E packaging cells 
as previously reported [21]. U937 cells $\left(2 \times 10^{5}\right.$ cells/well) were spin-infected (at $32^{\circ} \mathrm{C}$ for 90 $\min )$ in 96-well flat-bottomed plates in the presence of polybrene $(6 \mu \mathrm{g} / \mathrm{ml})$. The retrovirus-infected cells were selected with blasticidin S (10 $\mathrm{g} / \mathrm{ml})$ (Invivogen, San Diego, CA) for 14 days.

\subsection{Measurement of intracellular calcium concentration}

Serum-starved U937 cells $\left(5 \times 10^{5}\right.$ cells $\left./ \mathrm{ml}\right)$ were loaded with Indo-1 AM $(1 \mu \mathrm{M})$ (Dojindo, Mashiki, Japan) for $30 \mathrm{~min}$ at $37^{\circ} \mathrm{C}$. The cells were washed twice with Hanks' balanced salt solution (HBSS; Sigma) and resuspended in HBSS containing calcium chloride at a density of $5 \times 10^{5}$ cells $/ \mathrm{ml}$. The cell suspension $(2.5 \mathrm{ml})$ was transferred to a quartz cuvette with constant stirring and preheated for $5 \mathrm{~min}$ at $37^{\circ} \mathrm{C}$ in an $\mathrm{RF}-1500$ spectrofluorometer (Shimadzu, Kyoto, Japan). Cells were stimulated with S1P $(1 \mu \mathrm{M})$, LSF $(5 \mu \mathrm{M})$, or SPC (10 $\mu \mathrm{M})$ at $37^{\circ} \mathrm{C}$ as indicated. Time-lapse change of emission fluorescence intensity at $405 \mathrm{~nm}$ and $485 \mathrm{~nm}$ was measured upon excitation at $338 \mathrm{~nm}$ using an RF-1500. Digitonin was used to permeabilize cells and EGTA was employed to trap $\mathrm{Ca}^{2+}$ during compensation of emission signals. $\left[\mathrm{Ca}^{2+}\right]_{i}$ was calculated using a program pack for intracellular calcium measurement for the instrument (Shimadzu). $\mathrm{Ca}^{2+}$ influx of LPA2-RH7777 cells infected with MSCV-Gaq-I was measured by FLIPR Calcium assay 4 kit (Molecular devices) in accordance with manufacture's protocol. In brief, $1.5 \times 10^{4}$ cells were inoculated in half-sized black 96-well plate and incubated $4 \mathrm{hr}$ with serum-free medium. After loading with fluorescent calcium indicator, LPA $(10 \mu \mathrm{M})$ was injected in FLEX station II (Molecular devices) and time-lapse change in fluorescence (Ex $485 \mathrm{~nm}, \mathrm{Em} 525 \mathrm{~nm}$ ) was monitored.

\subsection{Statistical assessment of data}

Data shown on bar graphs are expressed as mean values of replicate in each assay. Values of standard error of deviation were indicated with lines on top. Statistical significance between data points was determined using Student's $t$-test and $P$ values were indicated in each graph. 


\section{RESULTS}

\subsection{Effect of LSF and SPC on TPA-induced expression of macrophage markers.}

Recently, bioactive lipids such as S1P and LPA were proposed to function in the context of cellular adhesion events, analogous to chemokines [14,15,22]. We tried to understand the involvement of less characterized bioactive sphingolipid species, SPC and LSF in monocytic cell differentiation to macrophage. We opted to examine the change of cell surface macrophage marker expression upon in vitro differentiation of monocytic cell line U937. U937 cells have been utilized to examine macrophagic differentiation of monocytic cells in vitro [23]. TPA triggers U937 differentiation into an immature macrophage intermediate state rather than mature macrophage-like cells when expression of cell surface receptors was examined [24]. TPA is known to induce an increase in the expression of CD11b (integrin $\alpha_{M}$ ) among differentiation markers [17]. We assessed the expression of CD11b by flow cytometry to determine whether these sphingolipids could affect differentiation. In such assay, LSF strongly suppressed, but SPC slightly enhanced, the TPA-induced CD11b expression in U937 cells (Fig. 1A) and THP-1 cells (Fig. 1B), whereas the effect of S1P on CD11b expression was inconsistent between the two cell lines although S1P is thought to be important for cell adhesion of macrophages[14,15,22]. Since enhancement by SPC was rather subtle in normal culture medium, stimulatory effect of SPC was examined in the culture medium containing charcoal treated FBS (likely depleting lipid content) for U937 cells. In such medium, TPA subtly induced CD11b whereas addition of SPC strongly enhanced the event in U937 cells (Fig. 1C). To determine macrophage marker expressed in matured macrophage, mannose receptor (CD206) induction was also examined. Only TPA-triggered SPC treated cells expressed detectable level of CD206 (Fig. 1C). These data indicated that serum content(s) affect the effect of SPC in the differentiation event. When THP-1 cells were examined, TPA strongly induced whereas addition of SPC exhibited subtle enhancement in CD11b staining. Neither condition induced detectable CD206 expression in THP-1 (Fig. 1C). These results were consistent with the previous report indicating that U937 cells more resemble human monocytes than THP-1 cells [25].

Polarized macrophage differentiation could account for the various biological functions of macrophages. Difference in marker expression could indicate the functional difference of 
macrophage. Differently activated macrophages could be classified into two major groups: classical macrophage (M1) or alternative macrophage (M2). The expression of interleukins 10 and 12 could be used to distinguish M1 and M2 subtypes. M2 macrophages could be further defined by the use of IL-6, TGF $\beta$, and CD23, although some of these markers are also expressed in M1 cells [26,27]. We analyzed the gene expressions of these marker proteins by RT-PCR in order to determine whether addition of SPC could change macrophage subtype from M1 subtype, which is induced by TPA alone. The gene expression profiles for TPAand the TPA plus SPC-induced macrophage were very similar in terms of marker expression, in which the induction of IL-10, 12, 6, and CD23 was detected but not TGF $\beta$ (Fig. 1D). This result indicated that SPC enhances the classical M1 macrophage differentiation of monocytic cells triggered by TPA. Taken together, these results suggest that LSF could suppress, but SPC could enhance, TPA-triggered monocyte differentiation into M1 macrophages.

\subsection{Effect of SPC and LSF on the Raf/MEK/ERK signaling pathway.}

TPA induces monocyte differentiation into macrophages through activation of the classical MAP kinase pathway composed by Raf-1, MEK1/2, and ERK1/2. SPC and S1P were reported to induce ERK1/2 phosphorylation in several cell lines, although they are not of monocytic origin [28]. Therefore, we tested the effect of LSF, SPC, and S1P on a signaling cascade involving Raf-1, MEK1/2, and ERK1/2 in U937 cells. Administration of TPA strongly induced the phosphorylation of Raf-1 (Ser 338), MEK1/2 (Ser217/221), and ERK1/2 (Thr202/Tyr204) (Fig. 2A). LSF inhibited phosphorylation of these proteins regardless of the presence of TPA (Fig. 2A). When U937 cells were maintained in normal culture medium containing serum, phosphorylation of the cascade was detectable, most likely due to basal stimulation from the content of the serum (i.e., growth factors). SPC was added to serum-starved U937 cells to reduce the background phosphorylation caused by these serum factors. Under such conditions, SPC transiently induced phosphorylation of Raf-1, MEK1/2, and ERK1/2 (Fig. 2B). S1P also induced phosphorylation of Raf-1, MEK1/2, and ERK1/2 (Fig. 2C), although S1P did not enhance monocyte differentiation into macrophages (Fig. 1). Consistently, LSF suppressed, but SPC induced, phosphorylation of ERK1/2 in THP-1 cells (Supplemental Fig.1 A,B). We next used a MEK-specific inhibitor, PD98059, to address whether activation of the Raf/MEK/ERK signaling pathway is required for enhancement of TPA-induced CD11b expression by SPC. Indeed, PD98059 inhibited CD11b expression 
TPA/SPC-treated cells when cultured in medium containing charcoal-treated FBS in dose-dependent manner (Fig. 2D). These results suggest that the Raf/MEK/ERK signaling pathway plays an important role in TPA-induced monocyte differentiation into macrophages, and SPC enhances, but LSF suppresses, this event. The inability of S1P to induce CD11b, despite its ability to induce MAP kinase activation, might indicate that MAP kinase activation is not sufficient and another signaling pathway also takes part in macrophage differentiation.

\subsection{Effect of SPC and LSF on the PI3K/Akt signaling pathway.}

During monocyte differentiation into macrophages, circulating monocytes attach to the endothelial cells, and this is followed by transmigration through the endothelial layer into the intima, where monocytes differentiate into macrophages [10]. Integrins are involved in the adhesion of circulating monocytes toward endothelial cells, and the initial adhesion is dependent on integrins [29]. Therefore, we tested the effect of SPC and LSF on the adhesion of U937 cells to fibronectin, which binds to $\beta_{1}$ integrins, as a model substrate. SPC enhanced, whereas LSF suppressed, the adhesion of U937 cells to fibronectin in the absence of TPA (Fig. 3A). Upon exposure to chemokines from inflamed tissues, monocytes trigger chemokine receptor signaling, which results in the activation of PI3K to enhance chemotaxis or adhesion to endothelial cells [30,31]. Therefore, PI3K activation in SPC-treated U937 cells was monitored by measuring hydrophobic motif phosphorylation of Akt. Consistently, SPC induced transient Akt phosphorylation at about 5 min after the stimulation (Fig. 3B). We next examined the effect of PI3K inactivation on cell adhesion to fibronectin. Pretreatment with LY294002, a specific but reversible PI3K inhibitor, attenuated the SPC-induced increase of adhesion of U937 cells to fibronectin (Fig. 3C). Less prominent inhibition was found in cells treated with PD98059. Concurrent loss of Akt phosphorylation was observed in LY294002-treated U937 cells (Fig. 3D). In contrast to SPC, LSF suppressed phosphorylation of Akt, regardless of the addition of TPA, which is consistent with the suppression of adhesion to fibronectin (Fig. 3E). These results suggest that SPC enhances adhesion of U937 cells to fibronectin through the PI3K/Akt signaling pathway. We also carried out these signal transduction assessments in THP-1 cells. Since obtained results for the response to SPC and LSF in THP-1 were similar to that of U937 cells, short term effects of SPC and LSF seemed to be universal to monocytic cell lines (Supplemental Fig. $1 A-C$ ). We also tried to assess the effect of LY294002 in U937 cell differentiation. However, prolonged exposure to this 
inhibitor caused cell lethality thus involvement of PI3K in CD11b expression could not be tested in the condition in which Akt phosphorylation is completely blocked. This result was consistent with the line of evidence that PI3K signaling pathway provide survival signal in cancer cells. We therefore titrate down LY294002 to compromise PI3K activity in differentiation assay without affecting cell viability. Indeed, cellular lethality was avoided in lower concentration ( 1 or $2 \mu \mathrm{M})$ of LY294002. Although inhibitory effect was predicted, $\mathrm{CD} 11 \mathrm{~b}$ induction was dose-dependently stimulated in this condition (Fig. $3 F$ ). These results indicated that PI3K pathway could work inhibitory to CD11b expression. Alternatively, since this concentration of LY294002 may not completely shut down SPC-induced Akt phosphorylation, prolonged mild PI3K inhibition may alters unidentified signal transduction event(s) other than specific to SPC.

\subsection{S1P receptor $(s)$ is not involved in the SPC/LSF response.}

SPC enhanced the adhesion of U937 cells to fibronectin, which was very similar to the effects of S1P [6]. Moreover, previous data showed that SPC could utilize $\mathrm{S}_{1} \mathrm{P}_{3}$, an S1P receptor, to induce an influx of calcium and eNOS activation in endothelial cells [32,33]. Alternatively, S1P might be delivered from SPC by autotaxin/lysophospholipase D [34,35], which is reported to be present in sera and may therefore be present in the FBS supplied in the culture medium. To determine whether S1P production was involved in this system, we measured cellular calcium influx after lipid stimulation. Both SPC and LSF caused calcium influx when administrated to Indo-1-loaded U937 cells (Fig. 4A). The calcium concentration peaked around $200 \mathrm{~s}$ after stimulation with either LSF or SPC. Maximum calcium concentration was higher in SPC-treated cells than in LSF-treated cells. When cells were stimulated by S1P, U937 cells also exhibited calcium influx, which reached a peak within 10 s, and this peak was much sharper than that of SPC or LSF (Fig. 4B). Repeated addition of $\mathrm{S} 1 \mathrm{P}$ resulted in a lack of calcium influx, indicating that the $\mathrm{S} 1 \mathrm{P}$ receptor was desensitized by primary stimulation (Fig. 4B). When SPC or LSF was used as secondary stimulant, influx caused by these lipids was not affected by S1P pre-desensitization (Fig. 4B). These results ruled out the involvement of S1P receptors on intracellular calcium mobilization induced by SPC or LSF. When a calcium channel inhibitor (SKF-96365 or 2-APB, $10 \mu \mathrm{M}$ ) was supplied to the culture during differentiation, cells underwent massive cell death; thus, any long-term requirement of calcium influx could not be determined. 
4.5 Involvement of $G_{i / o}$ proteins in SPC-induced activation of the Raf/MEK/ERK and PI3K/Akt signaling pathways.

SPC clearly stimulated cellular signaling, such as MAP kinase and PI3K activation. Thus, we focused on the cellular signaling downstream of possible GPCR(s) for SPC. SPC-induced ERK1/2 phosphorylation was severely inhibited by pretreatment with PTX, an irreversible blocker for $\mathrm{G}_{\mathrm{i} / \mathrm{o}}$ protein activation (Fig. 5A). Consistently, SPC-induced phosphorylation of Akt was also inhibited by PTX, although basal phosphorylation was not affected (Fig. 5A, Suppl Fig. 1C). These results suggest that SPC activates the Raf/MEK/ERK and PI3K/Akt signaling pathways via $\mathrm{G}_{\mathrm{i} / \mathrm{o}}$ proteins in U937 cells. In contrast, the inhibitory effect of LSF in TPA-mediated activation was not inhibited in the presence of PTX (Fig. 5B). Thus, the mode of action between SPC and LSF appeared to be independent.

\subsection{Involvement of $G_{q}$ proteins in $S P C$-induced intracellular calcium mobilization.}

Since both SPC and LSF elicited calcium influx, the possible involvement of $\mathrm{G}_{\mathrm{q}}$ proteins was predicted. Downstream signaling of $\mathrm{G}_{\mathrm{q}}$ proteins can be inhibited by the expression of the C-terminal peptide of $\mathrm{G \alpha}_{\mathrm{q}}$, which interacts with the intracellular region of agonist-activated GPCR, thus competing with endogenous $\mathrm{G} \alpha_{\mathrm{q}}$. The peptide was therefore designated as a $\mathrm{G} \alpha_{\mathrm{q}}$ inhibitor $\left(\mathrm{G \alpha}_{\mathrm{q}}-\mathrm{I}\right)$, and $\mathrm{G}_{\mathrm{q}}$ selective inhibition using this peptide has been reported both in vitro and in vivo $[20,36]$. We introduced $G \alpha_{\mathrm{q}}$-I-IRES-blasticidin to U937 cells with retrovirus-mediated gene transfer and a blasticidin S-resistant pool was selected to circumvent the cloning effect. We confirmed the expression of $\mathrm{G \alpha}_{\mathrm{q}}-\mathrm{I}$ in semi-quantitative RT-PCR, which resulted in a specific expression of $G \alpha_{q}-I$ mini gene (Supplemental Fig. 2). In control virus-infected cells (only encoding IRES-blasticidin without $G \alpha_{q}-\mathrm{I}$ ), both SPC and LSF induced consistent calcium influx (Fig. 5C). When $\mathrm{G}_{\mathrm{q}}$-I was introduced, SPC-induced calcium influx was partially inhibited. In contrast, LSF-induced calcium influx was not inhibited (Fig. 5C). To examine the completeness of inhibition, the effect of $\mathrm{G \alpha}_{\mathrm{q}}$-I was evaluated in $\mathrm{LPA}_{2}$-overexpressed McA-RH7777 cells, in which $\mathrm{LPA}_{2}$ is coupled to $\mathrm{G}_{\mathrm{q}}$ proteins [37]. The $\mathrm{G}_{\mathrm{q}}$-mediated calcium influx was attenuated when the inhibitor peptide was expressed in this cell line (Fig 5D). These results suggest that SPC and LSF induce calcium influx through distinct signaling pathways in which SPC utilizes $\mathrm{G}_{\mathrm{q}}$ proteins at least in part. 


\section{DISCUSSION}

\subsection{Intracellular signal transduction is involved in the functioning of SPC and LSF.}

Previous studies have shown that SPC induces ERK1/2 activation in several cell lines [38], although its biological consequences are not clear. In the present study, we showed that SPC activated the Raf/MEK/ERK signaling pathway in monocytic cell lines (Figs. 2B and 2D). In contrast, LSF suppressed the Raf/MEK/ERK signaling pathway in these same cells (Fig. 2A). As reported previously [39], PD98509, a MEK-specific inhibitor, inhibited TPA-induced differentiation of U937 cells into macrophages (Fig. 2D). PD98509 also suppressed enhancement of TPA-induced macrophagic differentiation by SPC (Fig. 2D). Therefore, the Raf/MEK/ERK regulatory activities of these lipids must be important for subsequent monocyte differentiation into macrophages. In this study, we also demonstrated that SPC promotes, but LSF inhibits, U937 cell adhesion to fibronectin through regulating the PI3K/Akt signaling pathway (Fig. 3). Fibronectin binds to $\beta_{1}$ integrins, mainly to the $\alpha_{5} \beta_{1}$ integrin as opposed to the $\alpha_{4} \beta_{1}$ and $\alpha_{v} \beta_{1}$ integrins. When monocytes initially adhere to endothelial cells, PI3K and $\beta_{1}$ integrins are activated $[29,40]$. Therefore, SPC and LSF might also modulate monocyte adhesion to endothelial cells in the course of monocyte differentiation.

\subsection{SIP receptors may not be involved in the functioning of SPC and LSF.}

SPC and LSF share similar structural features since both are lysosphingolipids composed of a long-chain base and a polar head group, in which a phosphocholine and a sulfated galactose occupy the head group of SPC and LSF, respectively. Thus, the inverse functions of the lipids in the differentiation into macrophages may be explained by the structural difference of the polar head groups that can be recognized by distinct receptor(s). Several studies have shown that S1P receptors are lower-affinity receptors for SPC [28,41]. Both SPC and LSF have been reported to cause calcium influx and Akt phosphorylation via $\mathrm{S}_{1} \mathrm{P}_{3}$ in endothelial cells [42]. Moreover, SPC was shown to inhibit the generation of reactive oxygen species and MCP-1 through $\mathrm{S}_{1} \mathrm{P}_{3}$ in vascular smooth muscle cells and aorta tissue [32]. Therefore the S1P receptors may be one possible cellular target for SPC and LSF. Since we found that both SPC and LSF trigger calcium influx, as does S1P in these cell lines, we tested whether S1P 
receptors are involved in SPC- or LSF signaling pathway in our system. SPC- or LSF-induced calcium influx was not affected by desensitization of S1P receptors in U937 cells (Fig. 4B). Consistently, S1P did not affect TPA-triggered monocyte differentiation into macrophages (Fig. 1). Therefore, S1P receptors are unlikely to be involved in the modulation of monocyte differentiation by LSF and SPC.

\subsection{Possible involvement of proton-sensing receptors in the functioning of SPC and LSF.}

Many reports have suggested that SPC is a ligand for OGR1, GPR4, and G2A, all of which belong to the OGR1 family of GPCR [37,43,44]. More recently, however, Ludwig et al. reported that OGR1 and GPR4 recognize protons as their ligands [45]. Subsequently, other OGR1 family receptors, G2A and TDAG8, were shown to have similar characteristics [46-48], although the ability of G2A to sense protons requires further confirmation [49]. It was reported that among lysosphingolipids, SPC and psychosine antagonize proton-sensing receptors $[46,50]$. Collectively, OGR1 family is now regarded as proton-sensing-GPCR that could be antagonized with lysosphingolipids. Indeed, we detected the mRNA expression of G2A, OGR1, and TDAG8 in U937 and THP-1 cells by RT-PCR (data not shown). However, since SPC and LSF inversely affected the differentiation of monocytic cells into macrophages throughout this study, it is difficult to explain the opposite functions of SPC and LSF on differentiation through antagonistic effects on the proton-sensing GPCR. With regard to LSF function, our results indicated that both PTX and Gq inhibitor had no effect on the cellular phenotypes of LSF, indicating that LSF may not use GPCR for its differentiation-inhibitory activity; these studies, however, did not conclusively exclude the involvement of proton-sensing GPCR. Ideally, further study is needed to determine whether SPC and LSF modulate TPA-triggered monocyte differentiation into macrophages via proton-sensing GPCRs in the monocytic cell lines U937 and THP-1.

\subsection{SPC-or LSF-mediated differential modulation of macrophage production in vivo.}

Correct participation of differentiated resident macrophages in various tissues is important for both innate and adaptive immunity. Lipid(s) circulating in body fluid or expressed in certain tissues can control the function of macrophages [51]. The possibility exists that SPC and LSF can modulate intracellular signaling and control monocyte differentiation and cellular adhesion in vivo. Nofer et al. reported that S1P, SPC, and LSF are present in high-density 
lipoprotein (HDL) [42,52,53]. HDL might be one of the major lipid carriers in the serum for delivery of (sphingo)lipids to monocytes. Therefore, the lipid content of HDL could mirror the lipid species in which monocytes are exposed. On the contrary, Kimura et al. have shown that the content of SPC and LSF in HDL as found by Nofer et al. was unlikely high [7]. Other than HDL-mediated delivery, expression in the plasma or local expression by endothelial cells are candidate production sites for these lipids. Our current findings could have a connection to the pathogenesis of atherosclerosis, in which pathogenic macrophages accumulate to form plaques on blood vessels. When model mice for atherosclerosis were treated with ISP-1/myriocin, a potent biosynthetic inhibitor of sphingolipid biosynthesis, a reduction of sphingomyeline, a possible metabolic precursor of SPC, occurred, which was coincident with a reduction of atherosclerotic lesions [9]. Although further detailed study is needed to conclusively appreciate the physiological and pathological effect of these lipids in macrophage production in vivo, the present elucidation of a mechanism involving SPC and LSF will provide not only a novel insight into the regulatory mechanisms of monocyte differentiation into macrophages but also a novel therapeutic target for atherosclerosis. 


\subsection{ACKNOWLEDGEMENT}

We thank Dr. Toshio Kitamura (University of Tokyo) for the Plat-A and Plat-E cells, Dr. Fumikazu Okajima (Gunma University) for the McA-RH7777 cells stably expressing LPA, and Dr. Jun Takasaki for the expression vector for $\mathrm{G \alpha}_{\mathrm{q}} \mathrm{I}$ (Astellas Pharma Inc., Tokyo, Japan). We also thank Dr. Gabor Tigyi (University of Tennessee) for helpful suggestions.

\subsection{FUNDING}

This work was supported by Grants-in-Aid for Scientific Research (19590065 to Y.K.) from the Japan Society for the Promotion of Science, and CREST, a grant-in-aid program, and a Grant-in-Aid for Creative Scientific Research (16GS0313) from the Ministry of Education, Culture, Sports, Science and Technology, Japan.

8.1 Abbreviations used: GPCR, G protein-coupled receptor; HDL, high-density lipoprotein; LPA, lysophosphatidic acid; LSF, lysosulfatide; PI3K, phosphatidylinositol-3-kinase; PTX, pertussis toxin; S1P, sphingosine-1-phosphate; SPC, sphingosylphosphorylcholine; TPA, 12-O-tetradecanoylphorbol 13-acetate. 


\section{FIGURE LEGENDS}

9.1 Fig. 1. Effect of SPC and LSF on TPA-induced marcophagic differentiation. A. B. U937 cells $(A)$ and THP-1 cells $(B)$ were incubated with S1P $(1 \mu \mathrm{M})$, LSF $(5 \mu \mathrm{M})$, or SPC $(10 \mu \mathrm{M})$ for $16 \mathrm{~h}$, followed by treatment with TPA $(1 \mathrm{ng} / \mathrm{ml})$ for $72 \mathrm{~h}$. The cells were stained with anti-CD11b antibody to determine differentiation into macrophages. Fluorescence intensity for anti-CD11b antibody staining was determined by flow cytometry. Similar results were obtained in additional sets of experiments $(n=3) . C$. Induction of macrophage markers upon TPA plus SPC stimulation. Stimulatory effect of SPC was assessed in a medium containing charcoal-treated FBS. Differentiation was induced as $A$ except the cells were overnight pretreated with the medium supplied charcoal-treated FBS. During the stimulations, the same medium was used. Anti-CD11b or CD206 was used for flow cytometric assessment. Similar results were obtained in multiple experiments $(\mathrm{n}=4)$. D. U937 cells were differentiated as in $A$ and the total RNA was prepared for indicated treatment. Reverse transcribed cDNA was assessed for gene expression of the indicated macrophage polarization markers. For $I L-10$ and 12 (p40), control template was prepared to assess the sensitivity of PCR conditions used. Control templates were serially diluted as indicated. Similar results were obtained in duplicate experiments.

9.2 Fig. 2. Effect of SPC and LSF on the Raf/MEK/ERK signaling pathway involved in CD11b expression. A. Suppression of the Raf/MEK/ERK signaling pathway by LSF. U937 cells were preincubated with the indicated concentration of LSF for $16 \mathrm{~h}$ and stimulated with TPA for $5 \mathrm{~min}$. Cell lysates were prepared as described in the Experimental Procedures. Changes in phosphorylation were detected by Western blotting analyses with the indicated phosphorylation-dependent and -independent antibodies. $B$ and $C$. Activation of the Raf/MEK/ERK signaling pathway by SPC $(B)$ or S1P $(C)$. U937 cells were starved of serum overnight and stimulated with SPC $(B)$ or S1P $(C)$ for the indicated times. Western blotting was carried out as in A. D. Effect of the MAP kinase inhibitor on macrophagic differentiation in the medium containing charcoal-treated FBS. Flow cytometric analysis for CD11b induction was performed as described in the Fig 1C. PD indicates U937 cells pretreated with PD98509 for 15 min prior to stimulations by SPC $(10 \mu \mathrm{M})$, followed by treatment with TPA (1 ng/ml). Similar result was obtained in duplicated experiment.

9.3 Fig. 3. Inverse effects of SPC and LSF on the PI3K/Akt pathway involved in adhesion to fibronectin. A. Effect of SPC and LSF on U937 cell adhesion to fibronectin. Serum-starved 
U937 cells were transferred to fibronectin-coated 96-well plates and stimulated with the indicated concentration of SPC or LSF for $1 \mathrm{~h}$. Non-adherent cells were washed off with serum-free medium and the resultant adherent cells were measured by XTT assay as described in the Experimental Procedures. Data are shown as the means of triplicate cultures, and bars represent standard errors of the mean. B. Activation of the PI3K/Akt signaling pathway by SPC. Serum-starved U937 cells were stimulated with SPC for the indicated times. Cell lysates were subjected to Western blotting with the indicated antibodies. $C$. Inhibition of SPC-induced adhesion of U937 cells to fibronectin by LY294002, an inhibitor of PI3 kinase(s). Serum-starved U937 cells were pretreated with LY294002 for $30 \mathrm{~min}$ prior to stimulation with SPC for $1 \mathrm{~h}$. Cell adhesion was determined as in $A$. Data are shown as the means of triplicate cultures, and bars represent standard errors of the mean. $D$. Inhibition of SPC-induced Akt phosphorylation by LY294002. Serum-starved U937 cells were pretreated with LY294002 for 30 min prior to the stimulation with SPC for $5 \mathrm{~min}$. Western blotting was carried out as in B. E. Suppression of Akt phosphorylation by LSF. U937 cells were treated as described in $A$. Cell lysates were subjected to Western blotting. Similar results were obtained in additional sets of experiments $(n=3)$. F. Induction of CD11b expression in the presence of low concentration of LY249002. U937 cells were differentiated as in Fig.1 $C$ in the presence of indicated concentration of LY249002 and CD11b was analyzed by flow cytometry. Relative expression of CD11b was calculated as a ratio to the untreated U937 cells. Similar results were obtained in duplicated experiments.

9.4 Fig. 4. Effect of SPC and LSF on $\mathrm{Ca}^{2+}$ influx. A. Induction of $\mathrm{Ca}^{2+}$ influx by SPC and LSF. Serum-starved U937 cells were loaded with Indo-1 AM ( $1 \mu \mathrm{M})$, stimulated with the indicated lysosphingolipids, and then further incubated in a time-lapse fluorescent detector to monitor changes in intracellular $\mathrm{Ca}^{2+}\left(\left[\mathrm{Ca}^{2+}\right]_{i}\right)$ as described in the Experimental Procedures. $B$. Failure of S1P to desensitize $\mathrm{Ca}^{2+}$ influx induced by SPC or LSF. Desensitization experiments were performed as described in A. After initial stimulation with S1P, cells were stimulated with the indicated lysosphingolipids. The arrows indicate the time of stimulation. Similar results were obtained in additional sets of experiments $(n=3)$.

9.5 Fig. 5. Effects of inhibitors of $\mathrm{G}_{\mathrm{i} / \mathrm{o}}$ and $\mathrm{G}_{\mathrm{q}}$ proteins on the functions of SPC and LSF. $A$ and $B$. SPC $(A)$ and LSF $(B)$ effect on ERK and Akt phosphorylation via $\mathrm{G}_{\mathrm{i} / \mathrm{o}}$ proteins. Serum-starved U937 cells were pretreated with pertussis toxin (PTX) for $16 \mathrm{~h}$ prior to stimulation with SPC $(A)$ or LSF $(B)$ for $5 \mathrm{~min}$. Cell lysates were subjected to Western blotting with the antibodies specific to ERK1/2 and Akt. Similar results were obtained in 
additional sets of experiments $(\mathrm{n}=3)$. C. Effect of $\mathrm{G} \alpha_{\mathrm{q}}$ inhibitor peptide $\left(\mathrm{G} \alpha_{\mathrm{q}}-\mathrm{I}\right)$ on $\mathrm{Ca}^{2+}$ influx induced by SPC or LSF. Serum-starved U937 cells expressing $G \alpha_{\mathrm{q}}$-I were loaded with Indo-1 AM (1 $\mu \mathrm{M})$, stimulated with the indicated lysosphingolipids, and then further incubated to monitor the change in $\left[\mathrm{Ca}^{2+}\right]_{i}$. U937 cells harboring empty vectors were employed as a control. Similar results were obtained in an additional set of experiments $(n=3)$. D. Effect of $\mathrm{G \alpha}_{\mathrm{q}}-\mathrm{I}$ on $\mathrm{LPA}_{2}$ receptor-mediated calcium influx. $\mathrm{G} \alpha_{\mathrm{q}}-\mathrm{I}$ was introduced to $\mathrm{LPA}_{2}$-transfected McA-RH7777 cells with ecotropic MSCV retrovirus vector packaged in Plat-E cells. When stimulated with $10 \mu \mathrm{M} L P A, G \alpha_{\mathrm{q}}$-I infected cells showed attenuated $\mathrm{Ca}^{2+}$ influx compared to vector control as expected. Results were reproduced in duplicated experiment. 


\section{REFERENCES}

1. J.C. Holthuis, T. Pomorski, R.J. Raggers, H. Sprong, and G. Van Meer, Physiol Rev 81 (2001) 1689-1723

2. Y.A. Hannun, and L.M. Obeid, Nat Rev Mol Cell Biol 9 (2008) 139-150

3. Y.A. Hannun, and R.M. Bell, Science 243 (1989) 500-507

4. B.J. Pettus, C.E. Chalfant, and Y.A. Hannun, Biochim Biophys Acta 1585 (2002) 114-125

5. S. Spiegel, and S. Milstien, Nat Rev Mol Cell Biol 4 (2003) 397-407

6. J.H. Paik, S. Chae, M.J. Lee, S. Thangada, and T. Hla, J Biol Chem 276 (2001) 11830-11837

7. T. Kimura, K. Sato, E. Malchinkhuu, H. Tomura, K. Tamama, A. Kuwabara, M. Murakami, and F. Okajima, Arterioscler Thromb Vasc Biol 23 (2003) 1283-1288

8. T. Fujita, K. Inoue, S. Yamamoto, T. Ikumoto, S. Sasaki, R. Toyama, K. Chiba, Y. Hoshino, and T. Okumoto, J Antibiot (Tokyo) 47 (1994) 208-215

9. M.R. Hojjati, Z. Li, H. Zhou, S. Tang, C. Huan, E. Ooi, S. Lu, and X.C. Jiang, J Biol Chem 280 (2005) 10284-10289

10. D.J. Rader, and E. Pure, Cell Metab 1 (2005) 223-230

11. S. Gordon, and P.R. Taylor, Nat Rev Immunol 5 (2005) 953-964

12. M. Matloubian, C.G. Lo, G. Cinamon, M.J. Lesneski, Y. Xu, V. Brinkmann, M.L. Allende, R.L. Proia, and J.G. Cyster, Nature 427 (2004) 355-360

13. E.J. Goetzl, and H. Rosen, J Clin Invest 114 (2004) 1531-1537

14. C.A. Durand, J. Westendorf, K.W. Tse, and M.R. Gold, Eur J Immunol 36 (2006) 2235-2249

15. S. Rieken, S. Herroeder, A. Sassmann, B. Wallenwein, A. Moers, S. Offermanns, and N. Wettschureck, J Biol Chem 281 (2006) 36985-36992

16. D.A. Tonetti, C. Henning-Chubb, D.T. Yamanishi, and E. Huberman, J Biol Chem 269 (1994) 23230-23235

17. K.N. Pennington, J.A. Taylor, G.D. Bren, and C.V. Paya, Mol Cell Biol 21 (2001) 1930-1941

18. S. Morita, T. Kojima, and T. Kitamura, Gene Ther 7 (2000) 1063-1066

19. H. Ohta, K. Sato, N. Murata, A. Damirin, E. Malchinkhuu, J. Kon, T. Kimura, M. Tobo, Y. Yamazaki, T. Watanabe, M. Yagi, M. Sato, R. Suzuki, H. Murooka, T. Sakai, T. Nishitoba, D.S. Im, H. Nochi, K. Tamoto, H. Tomura, and F. Okajima, Mol Pharmacol 64 (2003) 994-1005

20. J. Takasaki, T. Saito, M. Taniguchi, T. Kawasaki, Y. Moritani, K. Hayashi, and M. Kobori, J Biol Chem 279 (2004) 47438-47445

21. H. Yamamoto, H. Takematsu, R. Fujinawa, Y. Naito, Y. Okuno, G. Tsujimoto, A. Suzuki, 
and Y. Kozutsumi, PLoS One 2 (2007) e1232

22. H. Kanda, R. Newton, R. Klein, Y. Morita, M.D. Gunn, and S.D. Rosen, Nat Immunol 9 (2008) 415-423

23. P. Harris, and P. Ralph, J Leukoc Biol 37 (1985) 407-422

24. R. Hass, H. Bartels, N. Topley, M. Hadam, L. Kohler, M. Goppelt-Strube, and K. Resch, Eur J Cell Biol 48 (1989) 282-293

25. J. Prieto, A. Eklund, and M. Patarroyo, Cell Immunol 156 (1994) 191-211

26. A. Mantovani, A. Sica, S. Sozzani, P. Allavena, A. Vecchi, and M. Locati, Trends Immunol 25 (2004) 677-686

27. D.M. Mosser, and J.P. Edwards, Nat Rev Immunol 8 (2008) 958-969

28. J.R. Van Brocklyn, M.H. Graler, G. Bernhardt, J.P. Hobson, M. Lipp, and S. Spiegel, Blood 95 (2000) 2624-2629

29. F.W. Luscinskas, G.S. Kansas, H. Ding, P. Pizcueta, B.E. Schleiffenbaum, T.F. Tedder, and M.A. Gimbrone, Jr., J Cell Biol 125 (1994) 1417-1427

30. E. Hirsch, V.L. Katanaev, C. Garlanda, O. Azzolino, L. Pirola, L. Silengo, S. Sozzani, A. Mantovani, F. Altruda, and M.P. Wymann, Science 287 (2000) 1049-1053

31. R.E. Gerszten, E.B. Friedrich, T. Matsui, R.R. Hung, L. Li, T. Force, and A. Rosenzweig, J Biol Chem 276 (2001) 26846-26851

32. M. Tolle, A. Pawlak, M. Schuchardt, A. Kawamura, U.J. Tietge, S. Lorkowski, P. Keul, G. Assmann, J. Chun, B. Levkau, M. van der Giet, and J.R. Nofer, Arterioscler Thromb Vasc Biol 28 (2008) 1542-1548

33. H. Okamoto, N. Takuwa, Y. Yatomi, K. Gonda, H. Shigematsu, and Y. Takuwa, Biochem Biophys Res Commun 260 (1999) 203-208

34. M. Umezu-Goto, Y. Kishi, A. Taira, K. Hama, N. Dohmae, K. Takio, T. Yamori, G.B. Mills, K. Inoue, J. Aoki, and H. Arai, J Cell Biol 158 (2002) 227-233

35. T. Clair, J. Aoki, E. Koh, R.W. Bandle, S.W. Nam, M.M. Ptaszynska, G.B. Mills, E. Schiffmann, L.A. Liotta, and M.L. Stracke, Cancer Res 63 (2003) 5446-5453

36. S.A. Akhter, L.M. Luttrell, H.A. Rockman, G. Iaccarino, R.J. Lefkowitz, and W.J. Koch, Science 280 (1998) 574-577

37. I. Ishii, N. Fukushima, X. Ye, and J. Chun, Annu Rev Biochem 73 (2004) 321-354

38. E.S. Jeon, H.Y. Song, M.R. Kim, H.J. Moon, Y.C. Bae, J.S. Jung, and J.H. Kim, J Lipid Res 47 (2006) 653-664

39. M.B. Miranda, T.F. McGuire, and D.E. Johnson, Leukemia 16 (2002) 683-692

40. M.J. Lorenowicz, J. van Gils, M. de Boer, P.L. Hordijk, and M. Fernandez-Borja, J Leukoc Biol 80 (2006) 1542-1552 
41. H. Okamoto, N. Takuwa, K. Gonda, H. Okazaki, K. Chang, Y. Yatomi, H. Shigematsu, and Y. Takuwa, J Biol Chem 273 (1998) 27104-27110

42. J.R. Nofer, M. van der Giet, M. Tolle, I. Wolinska, K. von Wnuck Lipinski, H.A. Baba, U.J. Tietge, A. Godecke, I. Ishii, B. Kleuser, M. Schafers, M. Fobker, W. Zidek, G. Assmann, J. Chun, and B. Levkau, J Clin Invest 113 (2004) 569-581

43. H. Tomura, C. Mogi, K. Sato, and F. Okajima, Cell Signal 17 (2005) 1466-1476

44. G.F. Nixon, F.A. Mathieson, and I. Hunter, Prog Lipid Res 47 (2008) 62-75

45. M.G. Ludwig, M. Vanek, D. Guerini, J.A. Gasser, C.E. Jones, U. Junker, H. Hofstetter, R.M. Wolf, and K. Seuwen, Nature 425 (2003) 93-98

46. J.Q. Wang, J. Kon, C. Mogi, M. Tobo, A. Damirin, K. Sato, M. Komachi, E. Malchinkhuu, N. Murata, T. Kimura, A. Kuwabara, K. Wakamatsu, H. Koizumi, T. Uede, G. Tsujimoto, H. Kurose, T. Sato, A. Harada, N. Misawa, H. Tomura, and F. Okajima, J Biol Chem 279 (2004) 45626-45633

47. N. Murakami, T. Yokomizo, T. Okuno, and T. Shimizu, J Biol Chem 279 (2004) $42484-42491$

48. S. Ishii, Y. Kihara, and T. Shimizu, J Biol Chem 280 (2005) 9083-9087

49. C.G. Radu, A. Nijagal, J. McLaughlin, L. Wang, and O.N. Witte, Proc Natl Acad Sci U S A 102 (2005) 1632-1637

50. C. Mogi, H. Tomura, M. Tobo, J.Q. Wang, A. Damirin, J. Kon, M. Komachi, K. Hashimoto, K. Sato, and F. Okajima, J Pharmacol Sci 99 (2005) 160-167

51. H. Lee, J.J. Liao, M. Graeler, M.C. Huang, and E.J. Goetzl, Biochim Biophys Acta 1582 (2002) $175-177$

52. J.R. Nofer, M. Fobker, G. Hobbel, R. Voss, I. Wolinska, M. Tepel, W. Zidek, R. Junker, U. Seedorf, A. von Eckardstein, G. Assmann, and M. Walter, Biochemistry 39 (2000) 15199-15207

53. J.R. Nofer, B. Levkau, I. Wolinska, R. Junker, M. Fobker, A. von Eckardstein, U. Seedorf, and G. Assmann, J Biol Chem 276 (2001) 34480-34485 
A U937 cells

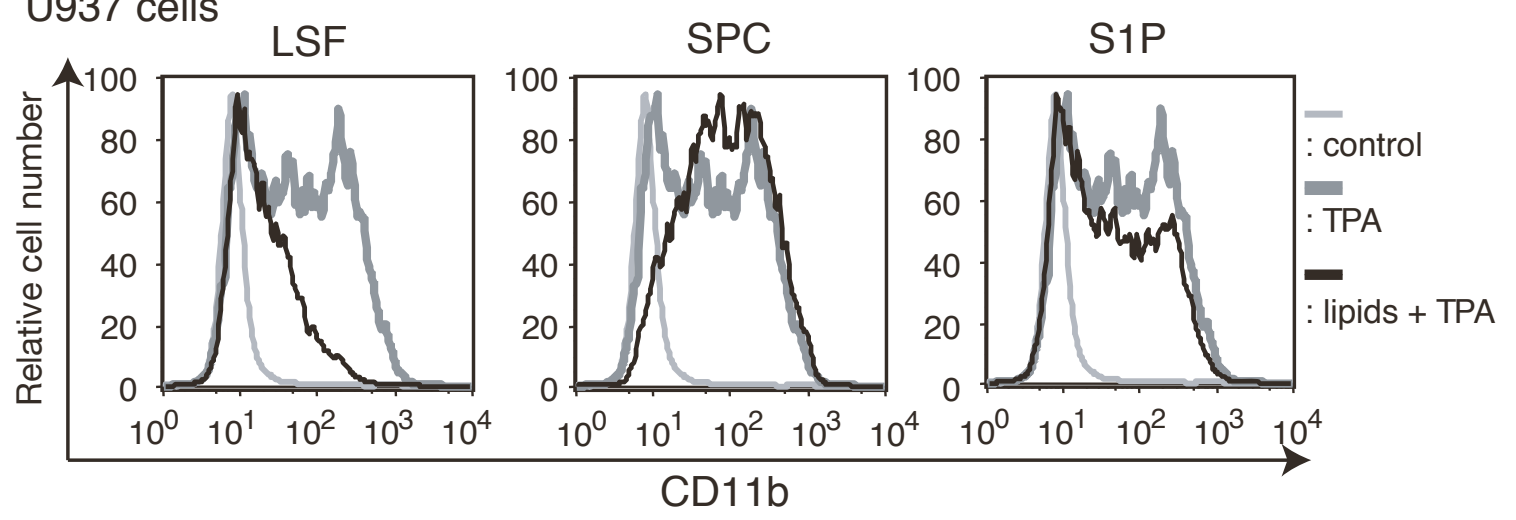

B THP-1 cells
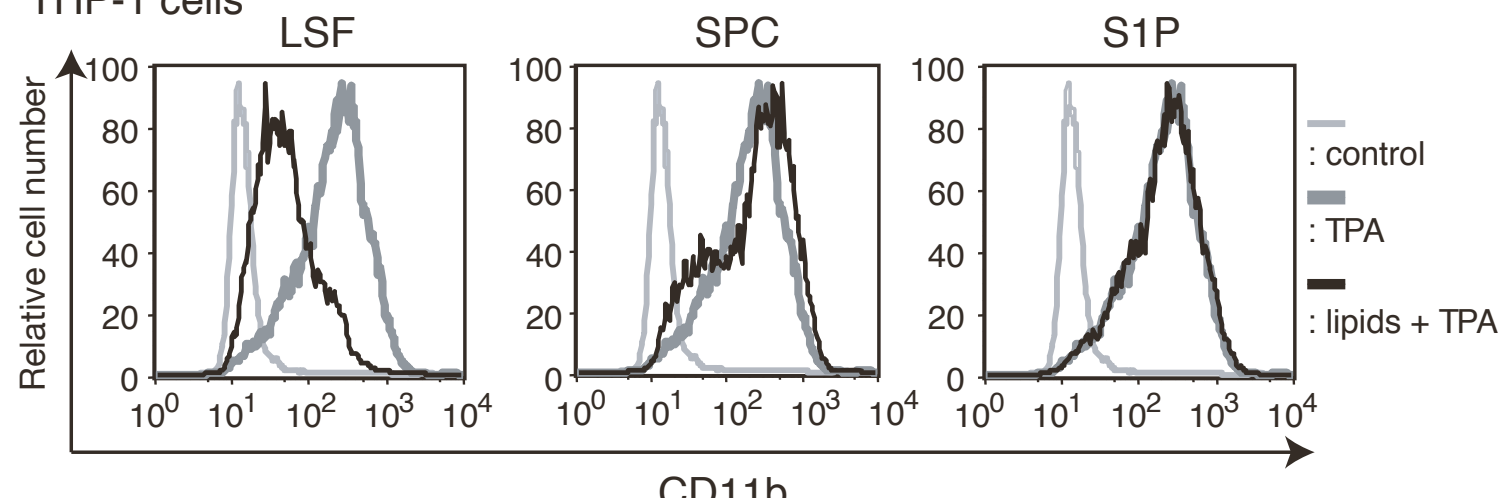

C

U937 cells
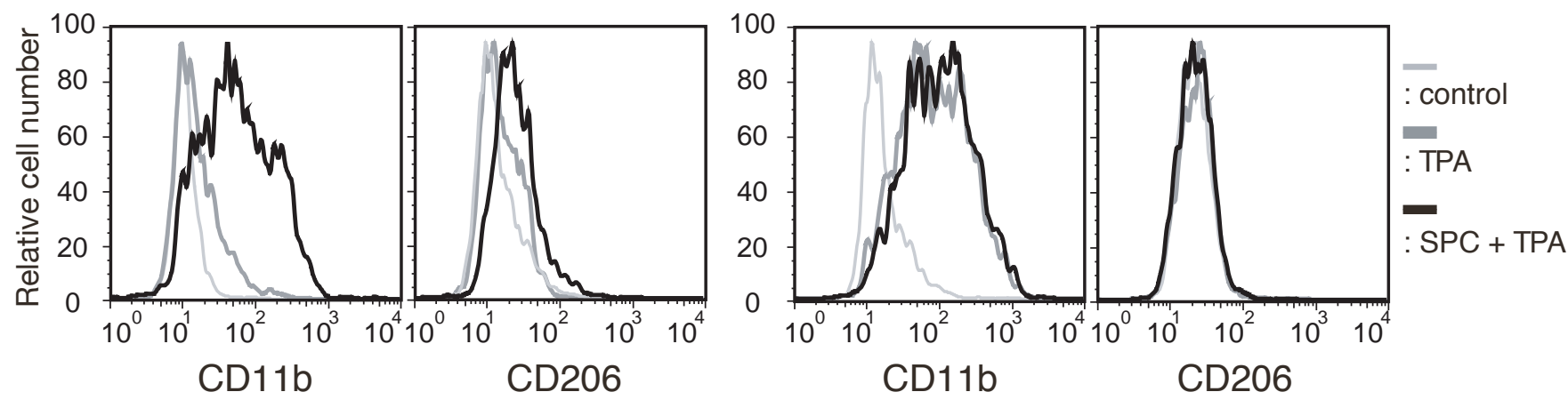

THP-1 cells

D
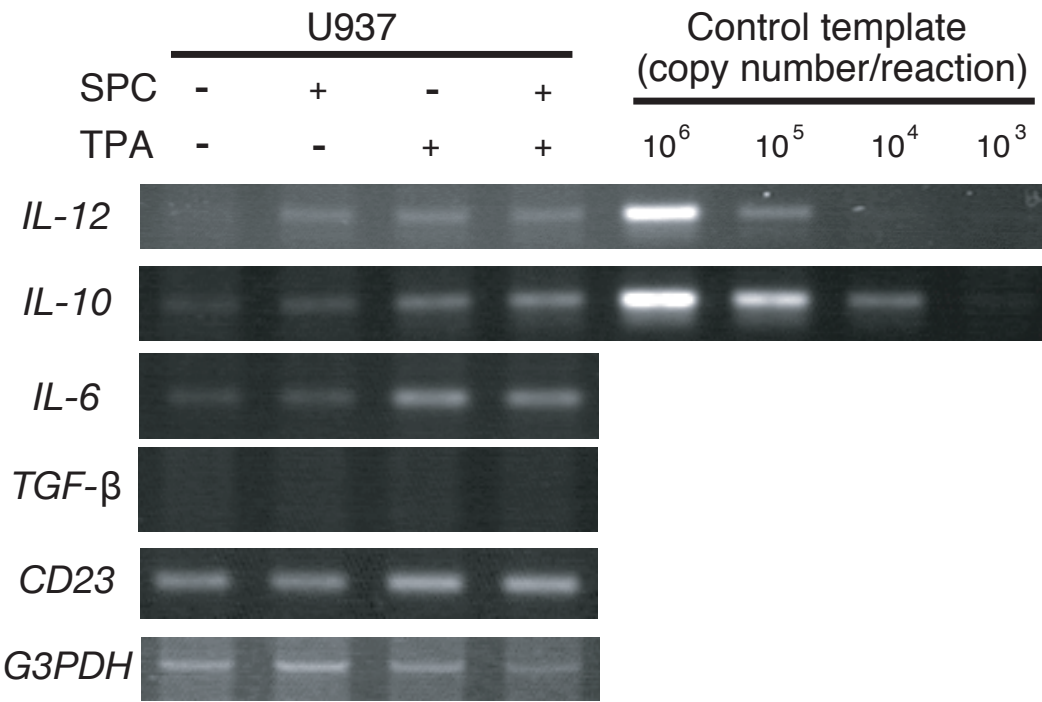
A

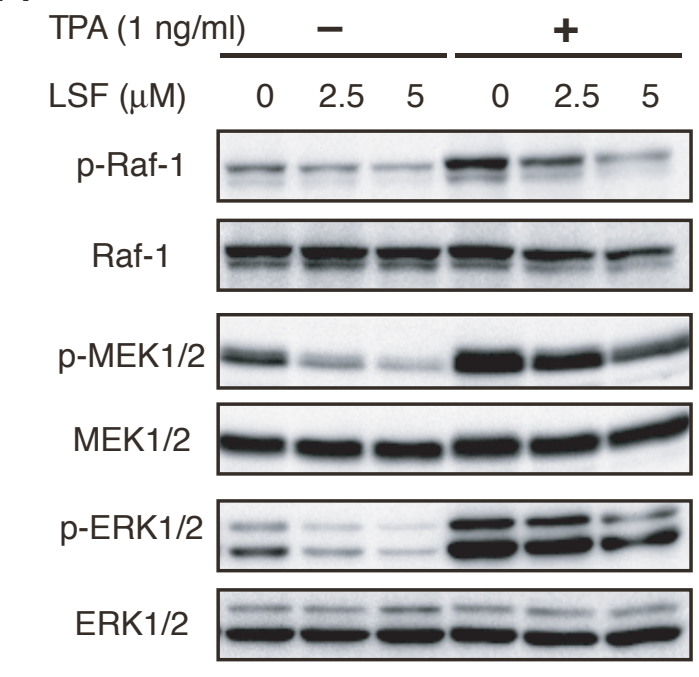

B
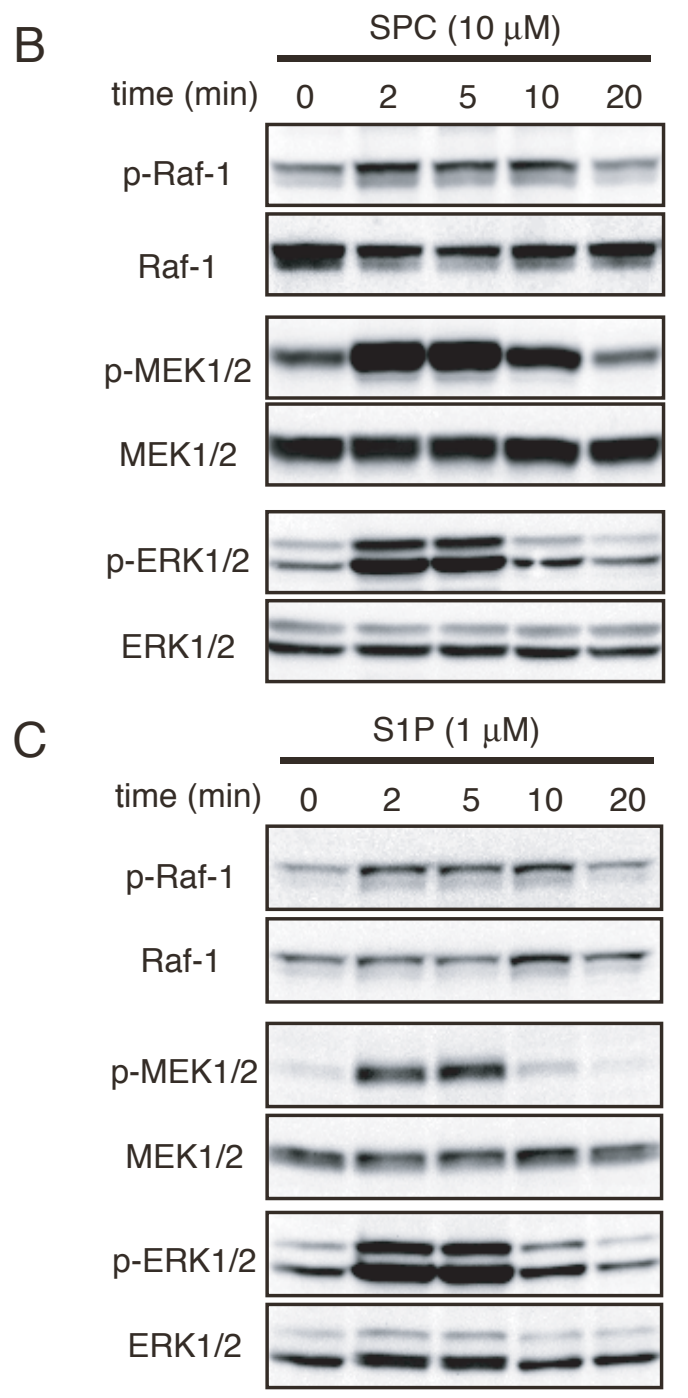

D

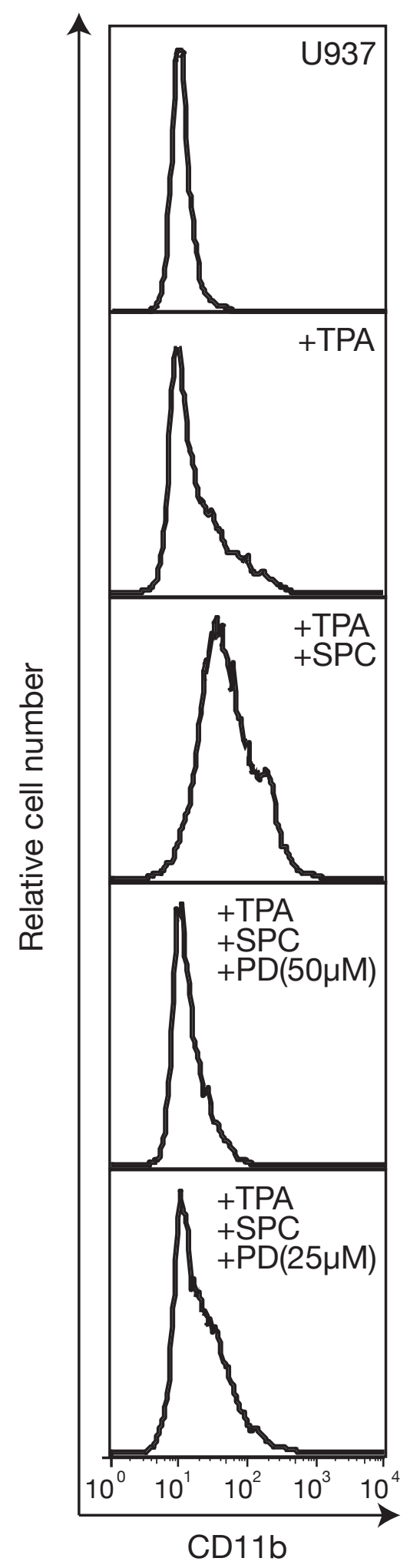

Figure 2 
A

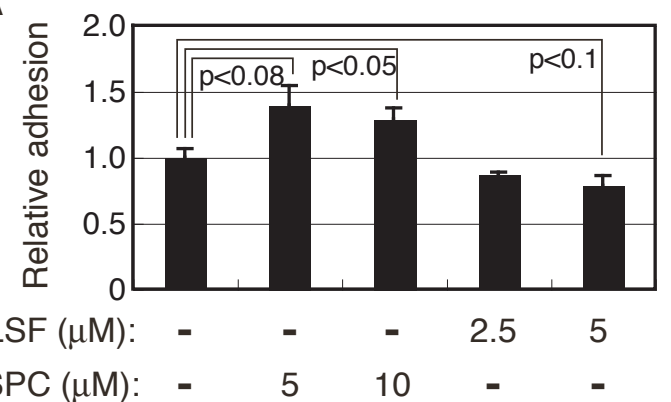

C

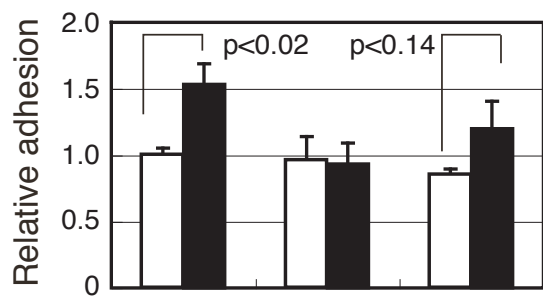

$\operatorname{SPC}(10 \mu \mathrm{M}) \quad-\quad+\quad+\quad-+$

LY294002 $(20 \mu \mathrm{M}) \quad-\quad+\quad+\quad-\quad$

PD $98509(20 \mu \mathrm{M}) \quad-\quad-\quad-\quad-\quad++$

E TPA $(1 \mathrm{ng} / \mathrm{ml})$

LSF $(\mu \mathrm{M})$

p-Akt

Akt

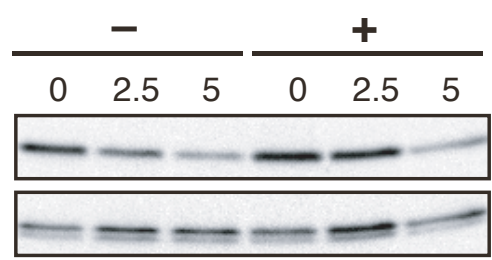

B

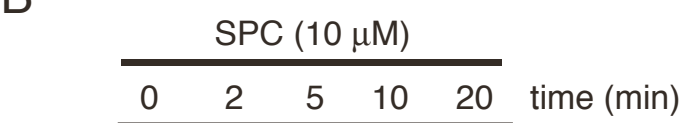

p-Akt

Akt

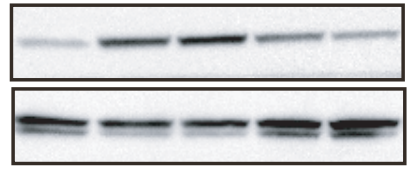

D

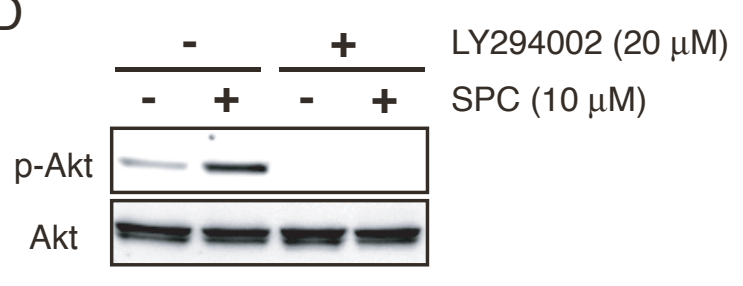

$\mathrm{F}$

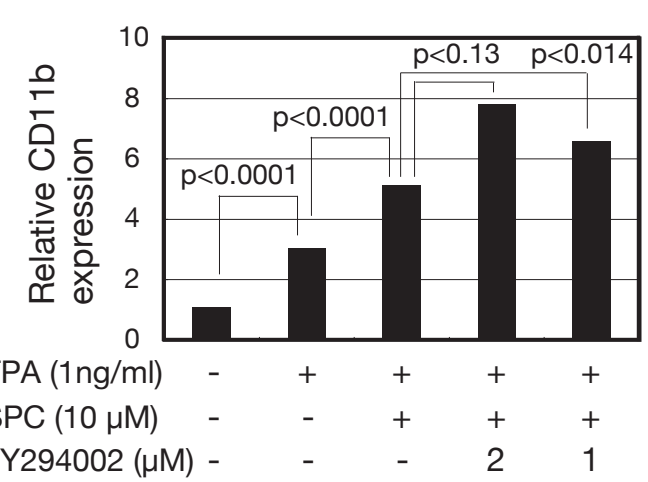

Figure 3 
A

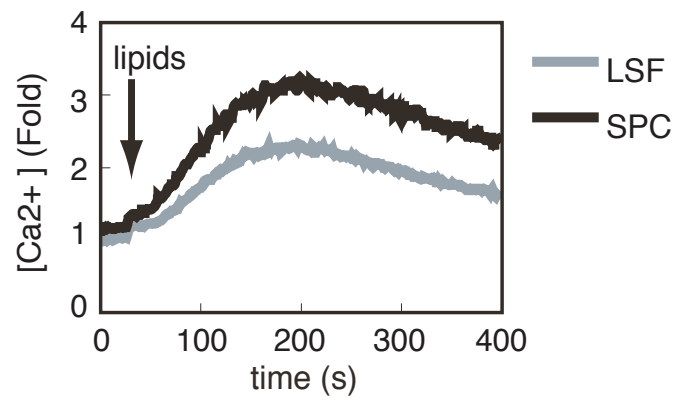

B

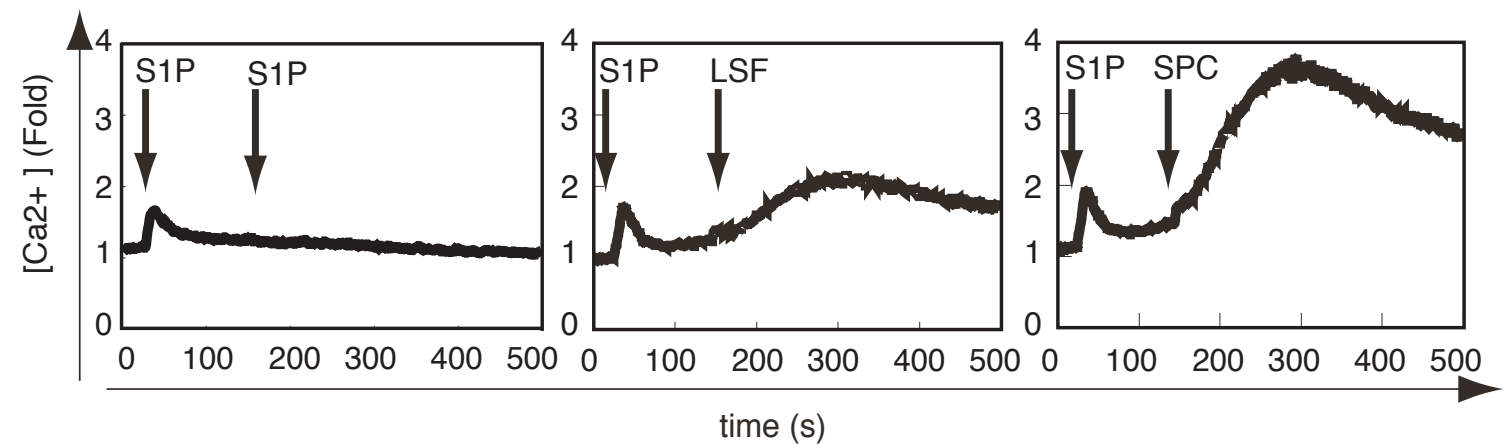

Figure 4

time (s) 
A

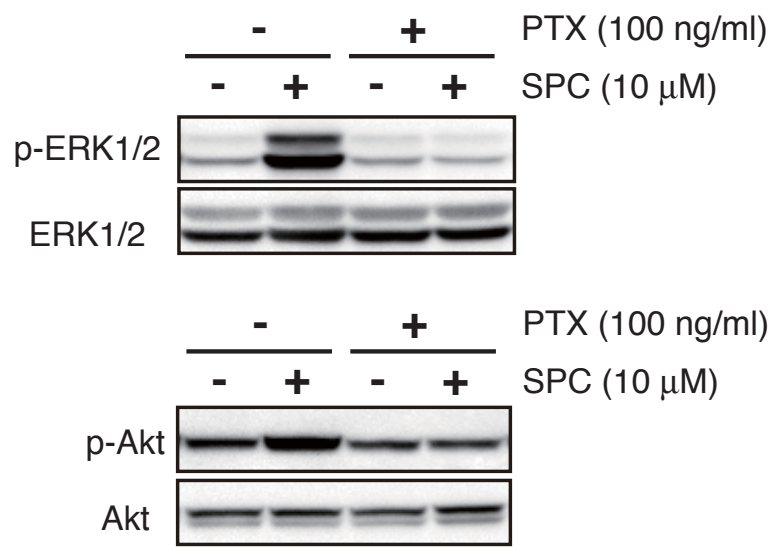

C

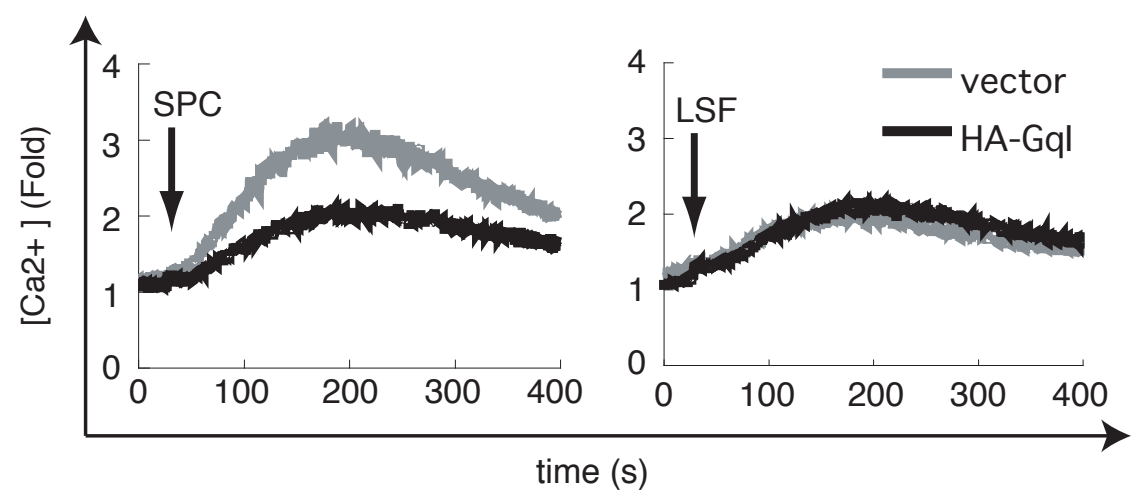

B

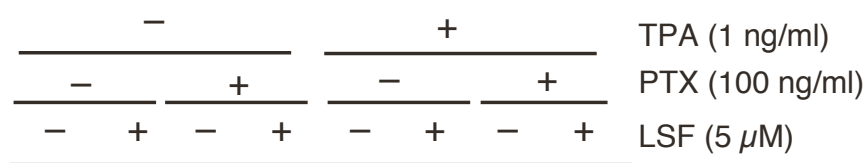

$p-E R K$

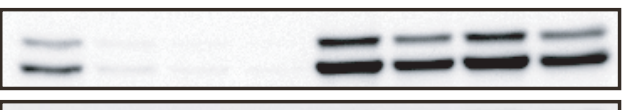

ERK

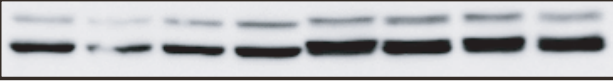

p-Akt

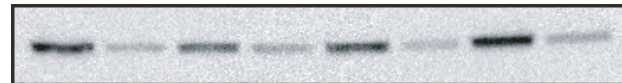

Akt

$-\longrightarrow+\cdots$
Figure 5

D

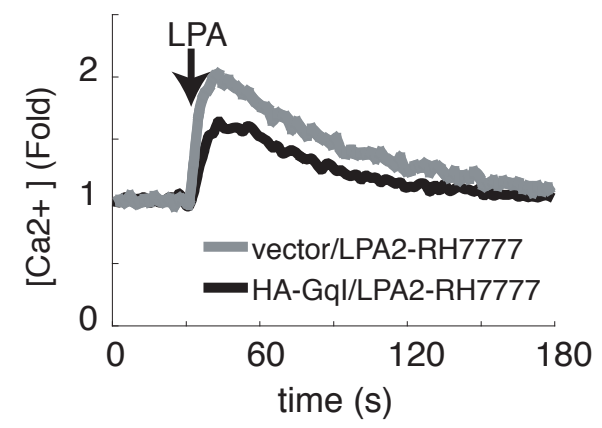




\section{Legends for supplemental figures}

\section{1-1 Supplemental figure 1}

Signal transduction properties of lysosphingolipid response in THP-1 cells

A. SPC-mediated activation of Raf-Mek-Erk pathway and Akt. THP-1 cells were stimulated with SPC and phosphorylation of Raf-Mek-Erk signaling pathway and Akt was examined as in Fig $2 B$ and Fig $3 B$, respectively. Consistent activation was also found in THP-1 cells. $B$. LSF-mediated suppression of Erk1/2 and Akt phosphorylation. THP-1 cells were treated with LSF as in Fig $2 A$ and Fig $3 E$. Consistent reduction of phosphorylation events was also detected in THP-1 cells. $C$. Suppression of SPC-mediated signaling by inhibitor treatment. Effect of PTX or LY294002 were assessed in THP-1 cells stimulated with SPC as in Fig 5A. Consistently, PTX partially and LY294002 strictly suppressed the phosphorylation of Akt. PTX inhibited SPC-induced phosphorylation of ERK1/2.

\section{1-2 Supplemental figure 2}

Retrovirus-mediated expression of HA-Gaq inhibitor peptide $\left(\mathrm{G} \alpha_{\mathrm{q}}-\mathrm{I}\right)$. U937 cells were infected with amphotropic MSCV-IRES-Blasticidin (Vector) or MSCV- G $\alpha_{q}-I$ -IRES-Blasticidin and polyclonally selected for 2 weeks. Total RNA was prepared and semi quantitative RT-PCR was carried out using a primer set specific to $G \alpha_{q}-I$. Since $G \alpha_{q^{-}} I$ mini gene does not have intronic sequence, amplification was carried out with control experiment without reverse transcription. Plasmid DNA of $G \alpha_{q^{-}} I$ retrovirus vector was used for positive control. We detected $G \alpha_{q^{-}} I$ expression only on cells with $G \alpha_{q^{-}} I$ infection with reverse transcription (HA-GqI). $G \alpha_{q}-I$-infected U937 cells were prepared in duplicated experiments and both of the blasticidin-selected cells expressed $G \alpha_{q}-I$. 
A

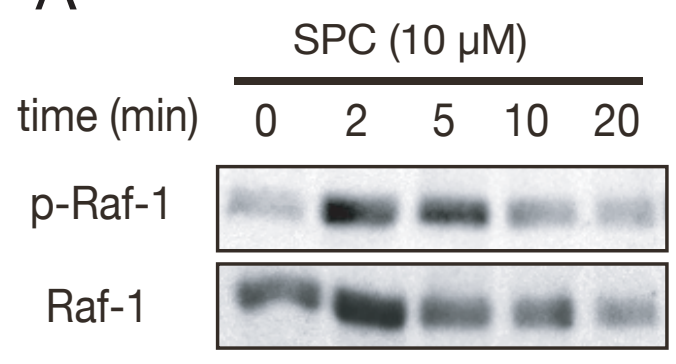

p-MEK1/2

MEK $1 / 2$

p-ERK1/2

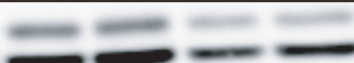

$\mathrm{ERK} 1 / 2=-$

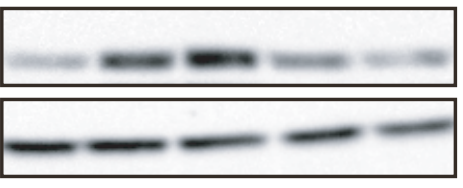

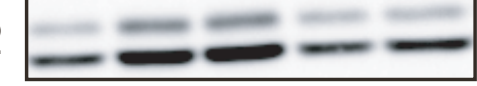
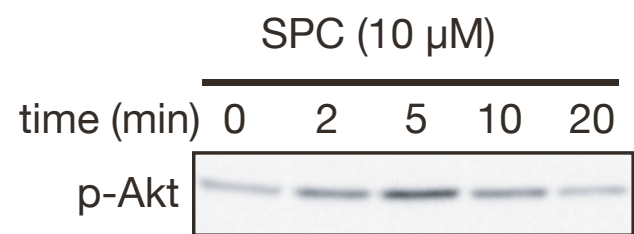

Akt

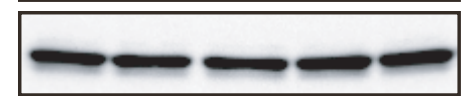

B TPA (1 ng/ml) LSF $(\mu \mathrm{M})$

\begin{tabular}{|c|c|c|}
\hline & & + \\
\hline 2.5 & 5 & 0 \\
\hline
\end{tabular}

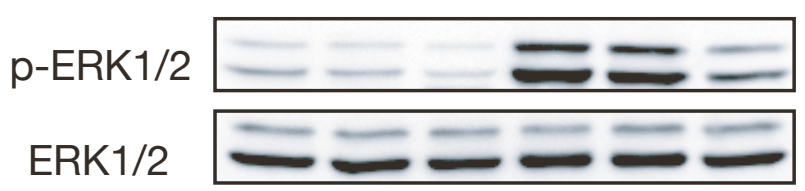

p-Akt

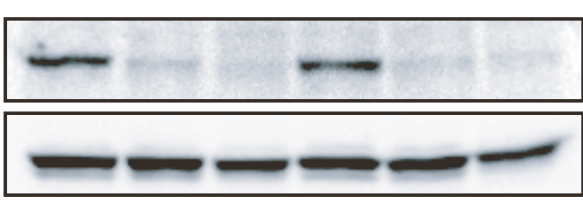

Akt

C $\quad \operatorname{sPC}(10 \mu \mathrm{M})$

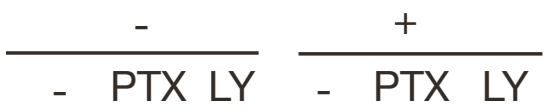

p-Akt

Akt

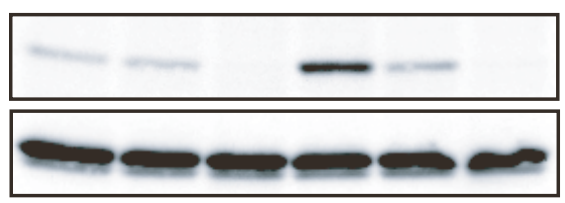

SPC $(10 \mu \mathrm{M})$

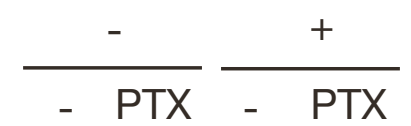

p-ERK $1 / 2=\square$

ERK1/2 


\section{Supplemental figure 2}

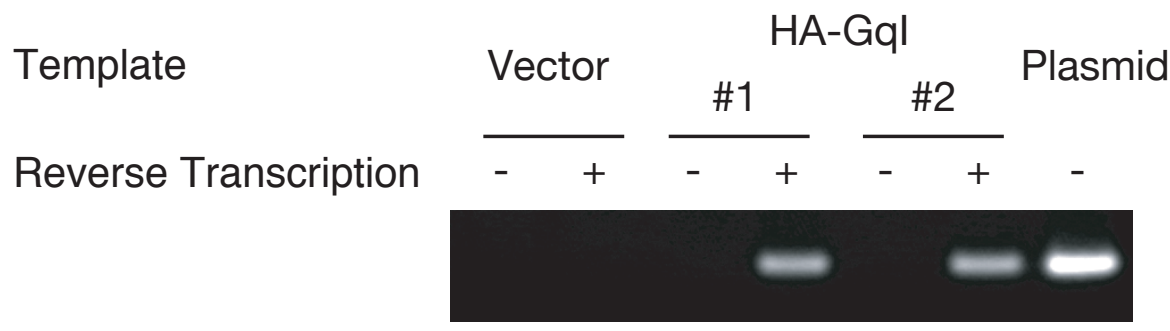

